\title{
Comparative analysis of the effects of Copaifera multijuga oil-resin and nitrofurazona in the cutaneous wound healing process
}

\section{Análise comparativa dos efeitos do óleo-resina de Copaifera multijuga e da nitrofurazona na cicatrização de ferida cutânea}

Carlos Augusto Nunes Martini ${ }^{1}$; João Guilherme Seifert Scapini ${ }^{1}$; Luiz Martins Collaço'; Anderson Matsubara ${ }^{1}$; Valdir Florêncio DA VEIGA JÚNIOR ${ }^{2}$.

\section{A B S T R A C T}

\begin{abstract}
Objectives: to evaluate, histologically and macroscopically, the influence of Copaifera multijuga (Copaiba) oil-resin on the healing process of cutaneous wounds, comparing it with nitrofurazone. Methods: we divided 36 rats into three groups of 12 animals, according to the treatment to be administered. Group SL (control) received saline on the lesion; the Group OIL received topical treatment with Copaiba oil; and the Group NITRO was treated with Nitrofurazone. We inflicted a circular wound of 8mm in diameter on the back of each animal. We subdivided each of the three groups of 12 animals into three subgroups, according to treatment time and euthanasia (7, 14 and 21 days). All animals received the proposed treatment daily. We photographed the lesions for area measurement, as well as for evaluation of macroscopic aspects. We resected and stained the scars to quantify and qualify elastic fibers, collagen, degree of epithelization, neovascularization and inflammation. Results: although the saline solution provided a faster wound closure in its initial phase, after 14 days the wound size of the three groups tested was the same. Levels of inflammation and neovascularization were similar in all three groups. The amount of collagen and elastic fibers was higher in the Nitrofurazone and Copaiba oil groups. Conclusion: in male Wistar rats, Copaifera multijuga oil-resin positively influences the healing process, but it is less effective than nitrofurazone in healing by secondary intention.
\end{abstract}

Keywords: Wound Healing. Plants, Medicinal. Collagen. Collagen Type I. Collagen Type III.

\section{INTRODUCTION}

I recent years, there has been a growing interest in folk medicine, with the use of natural products for the control of diseases ${ }^{1}$. Consequently, there was an increase in the number of herbal medicine, to obtain cheaper compounds with effects similar to traditional drugs ${ }^{2}$.

Although widely marketed and used by the population for the most varied purposes, Copaíba oil still leaves doubts as to its efficacy and safety. There are problems in its use, such as contamination, authenticity and the mixing with other oils of vegetable origin, which in addition to altering the possible desired therapeutic effect, can be detrimental to consumers' health ${ }^{3}$.

Found mainly in the biomes of the Amazon basin and the cerrado, the "copaibeira", as it is popularly known, is a tree belonging to the Copaifera genus, family of legumes, the main ones being $C$. officinaliis, C. reticulata, C. langsdorffii, C. guyanensis and $C$. multijuga, from whose trunks an oil-resin or balm can be extracted ${ }^{2,4,5}$. Used since the 16 th century for medicinal purposes ${ }^{2,6}$, Copaíba oil is described in the literature as anti-edematous $5^{5}$, anti-inflammatory ${ }^{3,7,8,}$ antibacteria| ${ }^{8,9}$, insecticide ${ }^{5,6,8}$, antifungal ${ }^{10}$ and wound healing ${ }^{8,11}$. It is popularly adopted in the treatment of several diseases, such as cystitis, bronchitis, chronic diarrhea, rheumatism, psoriasis, tumors $^{9}$ and gonorrhea ${ }^{4}$.

These therapeutic effects are due to the presence of diterpenes and sesquiterpenes ${ }^{12}$, such as copalic acid and $\beta$-caryophyllene sesquiterpenes and $\alpha$-copaene ${ }^{11}$. Paiva ${ }^{13}$ studied the formation of colitis induced by the application of acetic acid In rats and found Copaíba oil to be a potent anti-inflammatory agent, which was attributed to the fact that diterpene inhibited the transcription activity of the Nuclear-Kb Factor (FN-kB) ${ }^{11}$,

1 - Paraná Evangelical Faculty, Medicine Course, Curitiba, Paraná State, Brasil. 2 - Federal University of Amazonas, Department of Chemistry, Manaus, Amazonas State, Brazil. 
an important molecule involved in the cellular activation process of the innate immune response ${ }^{13}$.

Nitrofurazone is an antibactericidal agent of the furans family, whose mechanism of action is the inactivation of ribosomal proteins and other macromolecules, with consequent inhibition of proteins, DNA, RNA and cell wall synthesis, blocking the aerobic metabolism of bacterial cells. It can be used as adjuvant in the healing process of cutaneous wounds, since in addition to the antimicrobial activity, it interferes in the formation of granulation tissue. Its topical use is adequate, since it does not suffer significant absorption through whole or burned skin, nor through the mucosa ${ }^{14,15}$. It is found commercially as an ointment (30mg), at a concentration of $2 \mathrm{mg} / \mathrm{g}$.

The objective of this research was to histologically and macroscopically evaluate the influence of Copaifera multijuga oil-resin on wound healing of rats, comparing it with nitrofurazone.

\section{METHODS}

We used 36 adult, male rats of the same age, Rattus norvegicus albinus rodentia mammalia, from the Wistar line, from the TECPAR vivarium. All animals were acclimated and kept in the laboratory of the Paraná Evangelical Faculty (FEPAR), receiving water and chow for the species ad libitum, and respecting the ethical principles of animal handling and experimentation defined by the Animal Experiment Ethics Committee and the Brazilian Legislation on Animal Experimentation, Federal Law №6638, of 1979. The research project was submitted and approved by the Ethics Committee on the Use of Animals of FEPAR (protocol number 004988/2012).

We divided the sample into three groups of 12 animals each, according to the proposed treatment: the Control group (Group SL), received only $0.9 \%$ saline solution on the lesion; the Test Group (Group OIL) received topical treatment with pure Copaíba oil, at the dose of $0.3 \mathrm{ml} /$ day; the Comparison group (Group NITRO) was treated with topical Nitrofurazone (2mg/ $\mathrm{ml}) 0.3 \mathrm{ml}$ daily.
We weighed and identified all animals. We subdivided each of these groups into three cages, each with four animals, according to the time they would be submitted to euthanasia, seven, 14 and 21 days $^{16}$.

With the animal duly anesthetized with inhalational isofluorane in anesthetic bell until the deep plane, tricotomy was done on the back of the animal attached to a plank in the ventral decubitus position, with scissors and disposable razor ${ }^{2}$. Then, we performed the site antisepsis with $70 \%$ alcohol $^{3}$ and made a circular wound using a dermatological punch, measuring $8 \mathrm{~mm}$ in diameter, removing skin and subcutaneous, without damaging the underlying aponeurosis. Hemostasis was achieved by digital compression and gauze ${ }^{16}$.

All animals received the proposed topical treatment for each group daily, respecting the 24hour interval between the applications. In each of these applications, a gauze dressing was made around the animal with micropore tape, so that the animals were not subject to limitation of respiratory incursions and did not have direct contact with their wounds and the wounds of the other animals of the cage. We managed postoperative pain with tramadol $50 \mathrm{mg} / \mathrm{ml}$ at a dose of $5 \mathrm{mg} /$ day, intramuscularly for three days.

At the end of each pre-established period (7, 14 and 21 days), we again weighed four animals from each group and killed them by anesthetic overdose with inhaled isofluorane. The animals were then attached to the surgical board, where the lesions were analyzed macroscopically by highresolution photographs (8mp) obtained from a fixed camera on a pedestal, with an auxiliary light focus and a millimeter scale present in the field. We submitted the obtained images to software analysis (AutoCad 2013), and accurately measured the area of each wound ${ }^{16}$.

We resected the dead animals' cutaneous scars respecting a margin of at least $3 \mathrm{~mm}$ from the edge of the lesion, and immediately put them in previously identified flasks with buffered formalin. 


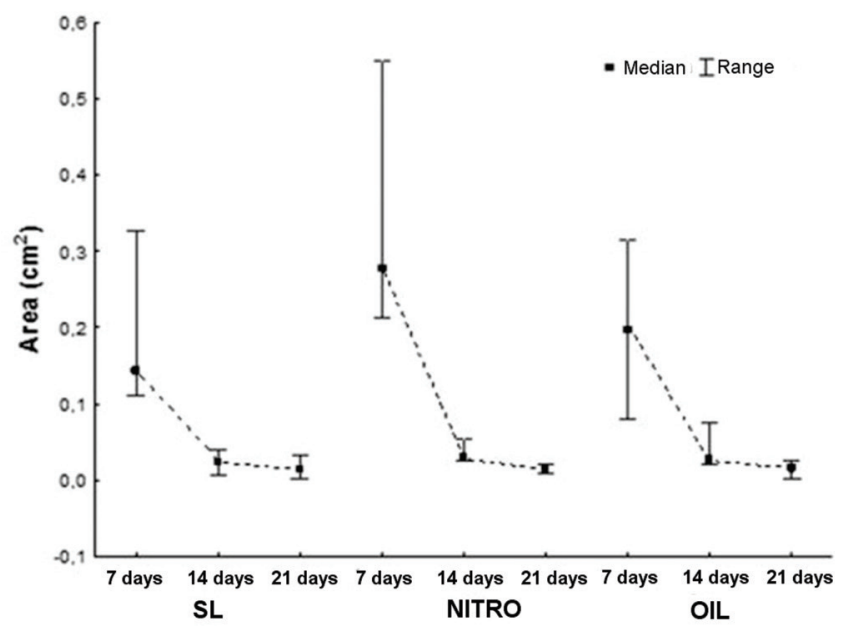

Figure 1. Wound area as a function of experiment time.

The FEPAR Histotechnical laboratory provided the preparation of the slides with Hematoxylin and Eosin (HE) staining for morphometric analysis (epithelization, classification and degree of inflammatory process, and vascularization), Sirius-red staining (quantified and qualified collagen, types I or III) and Weigert staining for analysis of elastic fibers. The same pathologist evaluated all HE slides with a optical microscopy, without being aware of the group they belonged to. For the evaluation of the amount and type of collagen fibers, as well as the amount of elastic fibers, we captured five images from each wound, with the aid of a microscope with coupled camera and polarized light lens. We then submitted the images to the ImagePro 2013 software, which counted the amount of type I and type III collagen fibers in each slide, as well as counting the elastic fibers ${ }^{17}$.

For the description of quantitative variables, we considered the mean, median, minimum value, maximum value and standard deviation. For the

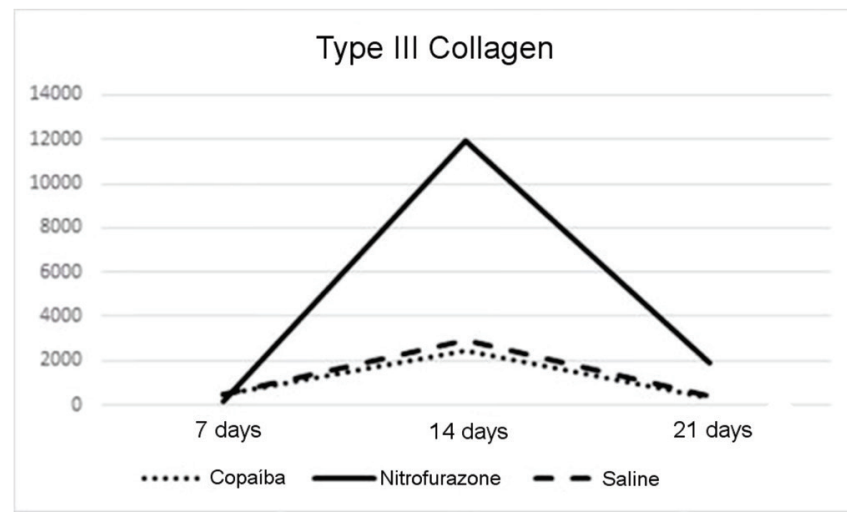

Figure 2. Type III collagen fibers.

description of qualitative variables, we used frequencies and percentages. We used the non-parametric KruskalWallis test to compare independent groups (groups at each moment and moments within each group), with $p$-values lower than 0.05 indicating statistical significance. We analyzed the data with the statistical software Statistica, v.8.0. All the results received statistical treatment, adopting $p<0.05$ as the level of significance.

\section{RESULTS}

We compared the groups at each moment by testing the null hypothesis of equal results in the three groups versus the alternative hypothesis of different results. When comparing the areas of the wounds to each other within the same moment of the experiment, we observed no statistical significance ( $p>0.05$ ). Although the groups SL and OIL had better results in the first seven days, on the 14th day of the experiment

Table 1 - Wound epithelialization by group according to the day of analysis

\begin{tabular}{ccccccc}
\hline & \multicolumn{2}{c}{ SL Group } & \multicolumn{2}{c}{ NITRO Group } & \multicolumn{2}{c}{ OIL Group } \\
Days of evolution & Present & Absent & Present & Absent & Present & Absent \\
\hline 7 & 1 & 3 & 4 & 0 & 4 & 0 \\
14 & 4 & 0 & 4 & 0 & 4 & 0 \\
21 & 4 & 0 & 4 & 0 & 4 & 0 \\
Total & 9 & 3 & 12 & 0 & 12 & 0 \\
\hline
\end{tabular}




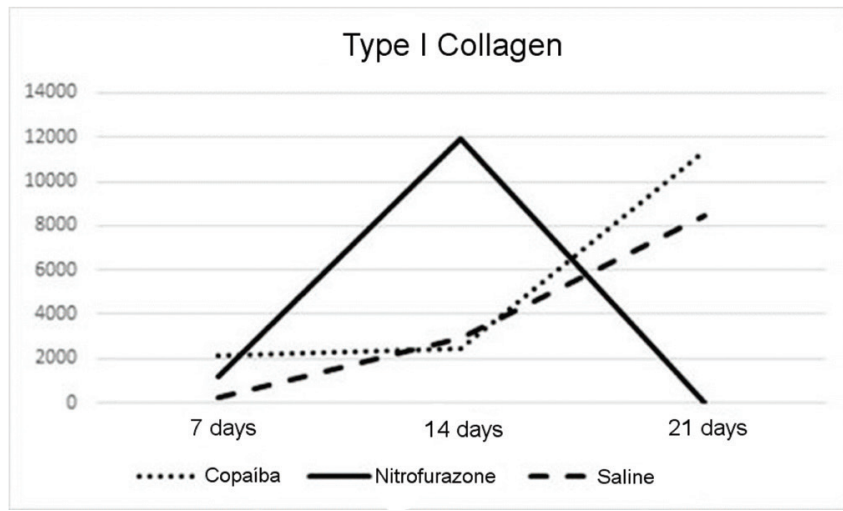

Figure 3. Type / Collagen fibers.

all the animals had wounds of very similar area, remaining in this tendency until complete healing. Figure 1 shows the statistics of the area variable as a function of time within each group.

We analyzed inflammation, epithelization and neovascularization based on histopathological analysis of the HE-stained slides (Tables 1, 2 and 3).

By analyzing and quantifying types III and I collagen fibers in each group and comparing with the time of analysis, we obtained the data shown in Figures 2 and 3.

We observed that saline had the worst performance, not stimulating the production of collagen in the same proportion as the other tested compounds. Copaíba oil was more capable of converting type III (young) collagen to type I (mature) collagen, a fact that has a positive effect, since the higher the amount of mature collagen, the greater the wound's mechanical resistance.

Applting the same method used to measure the collagen fibers (except for the staing used, the Weigert's), we obtained an estimate of the amount of

\section{Elastic Fibers}

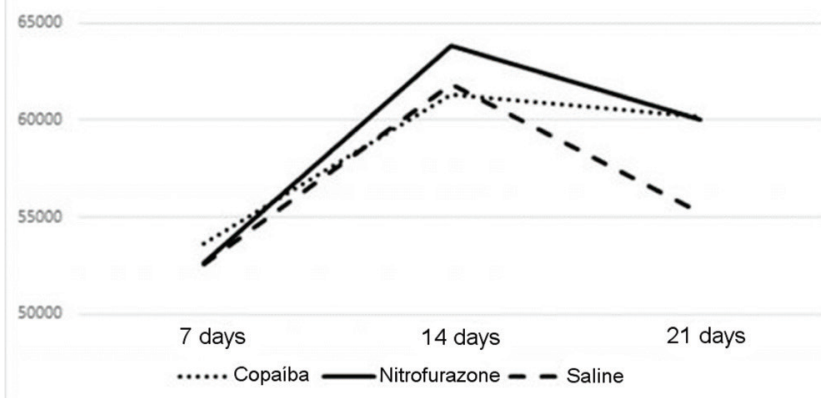

Figure 4. Elastic fibers.

elastic fibers in each wound (Figure 4). Elastic fibers are essential in that they give elasticity to the tissue, but as the latter gets more mature, the tendency is for some of them to join the collagen fibers, thus making the tissue more resistant.

\section{DISCUSSION}

Brazil has a rich flora in plants and compounds for medicinal use, a fact that has aroused more and more the interest of researchers, institutions and universities interested in herbal treatments or in search of new substances. Since not only the Copaíba oil but also other compounds have innumerable varieties of species within nature, standardizing research methods, as well as finding studies that can be directly compared, is a challenge.

Cutaneous healing is a complex process, influenced by a number of factors, such as nutritional status, systemic diseases, concomitant local or systemic infection and wound extension among others. In the present study, we chose Wistar rats due to the richness

Table 2- Presence of inflammation in the wound by group according to the day of analysis

\begin{tabular}{ccccccc}
\hline & \multicolumn{2}{c}{ SL Group } & \multicolumn{2}{c}{ NITRO Group } & \multicolumn{2}{c}{ OIL Group } \\
Days of evolution & Present & Absent & Present & Absent & Present & Absent \\
\hline 7 & 4 & 0 & 4 & 0 & 4 & 0 \\
14 & 2 & 2 & 1 & 3 & 4 & 0 \\
21 & 2 & 2 & 0 & 4 & 0 & 4 \\
Total & 8 & 4 & 5 & 7 & 8 & 4 \\
\hline
\end{tabular}


Table 3 - Wound neovascularization by group according to the day of analysis

\begin{tabular}{ccccccc}
\hline & \multicolumn{2}{c}{ SL Group } & \multicolumn{2}{c}{ NITRO Group } & \multicolumn{2}{c}{ OIL Group } \\
Days of evolution & Present & Absent & Present & Absent & Present & Absent \\
\hline 7 & 4 & 0 & 4 & 0 & 4 & 0 \\
14 & 4 & 0 & 4 & 0 & 4 & 0 \\
21 & 4 & 0 & 2 & 2 & 4 & 0 \\
Total & 12 & 0 & 10 & 2 & 12 & 0 \\
\hline
\end{tabular}

of data available in the literature on the characteristics of the skin and the cicatricial process of these animals, as well as the great resistance they display to infectious processes and surgical aggressions, besides being easy to obtain and to handle. The animals selected for the study were necessarily male, so that there was no interference of the hormonal variation due to females' estrous cycle, which could interfere in the tissue repair process $^{16}$.

We observed no significant difference between the mean areas of the wounds, except that the wounds of the nitrofurazone group had a smaller tendency to reduce size on the 7th day when compared with the two other groups, a difference that we did not observe at 14 and 21 days, a fact corroborated by other studies ${ }^{18}$.

The findings of inflammation, epithelialization and neovascularization were similar to those observed by Teixeira ${ }^{18}$, and we could observe a greater presence of inflammatory component in the Copaíba group, with evolution to the disappearance of the inflammatory process at day 21 in all groups. All the wounds showed an excellent capacity of neoangiogenesis and, in light microscopy, a rich capillary network with endothelial and red blood cells, which is in agreement with Estevão's findings ${ }^{19}$.

In the quantification of collagen fibers, we found that at day seven, Copaíba oil was more effective than the other two compounds in the induction of collagen formation, predominantly of type I. This differs from the work of Vieira et al. ${ }^{3}$, who found that the animals of the Copaíba oil group presented less collagen fibers when compared with the animals of the saline group. This divergence of data may be because they used Copaifera reticulata instead of Copaifera multijuga, used in this study.

At 14 days, there was an expressive increase in the amount of collagen of both types I and III in the wounds of the nitrofurazone group, reaching levels close to those of healthy skin (4:1 ratio). There was not a significant increase in the number of such fibers in the Copaíba group, the same happening in the saline group.

With 21 days of experiment, we could observe that both the OIL and NITRO groups reached good levels of collagen fibers, enough to maintain tissue resistance and retraction force. Saline did not prove to be a good agent inducing the formation of collagen fibers, with approximately $20 \%$ less collagen fibers than the other groups.

By the Weigert coloration, we could measure the amount of elastic fibers in each wound. These give greater elasticity to the tissue, besides interspersing with the collagen, conferring greater resistance. Nitrofurazone proved to be the best inducer of elastic fiber formation, but was closely monitored by the other two groups until the 14th day. On day 21 , there was a large drop in elastic fiber levels in the SL group, and the NITRO and OIL groups finished the experiment with very similar levels.

In Wistar male rats, Copaíba oil contributed positively to the healing of cutaneous wound by secondary intention, but due to the difficulty of obtaining an oil-resin with good origin, its use is limited. The authors suggest works on the systemic effects of the use of the Copaíba oil, to gather more scientific data and to obtain a basis for the use of this compound by the population. 


\title{
R E S U M O
}

\begin{abstract}
Objetivo: avaliar histologicamente e macroscopicamente a influência do óleo-resina de Copaifera multijuga no processo de cicatrização de feridas cutâneas, comparando com o grupo submetido ao uso da nitrofurazona. Métodos: foram utilizados 36 ratos, divididos em três grupos de 12 animais, conforme o tratamento a ser administrado. Grupo SF (controle, recebeu soro fisiológico sobre a lesão), Grupo ÓLEO (tratamento tópico com óleo de Copaíba), Grupo NITRO (tratamento tópico com Nitrofurazona). Foi confeccionada uma ferida circular de $8 \mathrm{~mm}$ de diâmetro no dorso de cada animal. Cada um dos três grupos de 12 animais foi subdividido em três subgrupos, de acordo com o tempo de tratamento e de eutanásia (7, 14 e 21 dias). Todos os animais receberam o tratamento proposto diariamente. As lesões foram fotografadas para mensuração de sua área, bem como, avaliados aspectos macroscópicos. As cicatrizes foram ressecadas e coradas, para quantificar e qualificar as fibras elásticas, colágenas, grau de epitelização, neovascularização e inflamação. Resultados: embora o soro fisiológico tenha proporcionado um fechamento mais rápido da ferida em sua fase inicial, a partir de 14 dias o tamanho das feridas dos três grupos testados se equivaleu. Níveis de inflamação e neovascularização foram semelhantes nos três grupos. A quantidade de fibras colágenas e elásticas foi maior nos grupos Nitrofurazona e Óleo de Copaíba. Conclusão: em ratos machos da linhagem Wistar, o óleo-resina de Copaifera multijuga influencia positivamente no processo de cicatrização, porém é menos eficaz que a nitrofurazona na cicatrização por segunda intenção.
\end{abstract}

Descritores: Cicatrização. Plantas Medicinais. Colágeno. Colágeno Tipo I. Colágeno Tipo III.

\section{REFERENCES}

1. Barbosa MH, Zuffi FB, Maruxo HB, Loamí L, Jorge LLR. Therapeutic properties of propolis for treatment of skin lesions. Acta Paul Enferm. 2009; 22(3):318-22.

2. Cavalcanti Neto AT, Arruda TEP, Arruda TTP, Pereira SLS, Turatti E. Análise comparativa entre o óleo-resina de copaíba e o digluconato de clorexidina no processo de cicatrização tecidual. Estudo histológico em dorso de ratos. Rev Odontol UNESP. 2005;34(2):107-12.

3. Vieira RC, Bombardiere E, Oliveira JJ, Lino Jr RS, Brito LAB, Junqueira-Kipnis AP. Influência do óleo de Copaifera langsdorffii no reparo de ferida cirúrgica em presença de corpo estranho. Pesq Vet Bras. 2008;28(8):358-66.

4. Brito NMB, Kulay Jr L, Simões MJ, Mora AO, Diniz JA, Lamarão LG. Estudo ultraestrutural do colo uterino de ratas ooforectomizadas após aplicação de óleo de copaíba. Acta Cir Bras. 2000;15(4):201-6.

5. Muniz JWC, Bozza PT, Nascimento JL, Reis PA. Atividade anti-inflamatória do óleo-resina da copaífera reticulata em modelo inflamatório de edema de pata. Rev Para Med. 2009;23(1).

6. Arroyo-Acevedo J, Quino-Florentini M, Martínez-Heredia J, Almora-Pinedo Y, Alba-González A, Condorhuamán-Figueroa M. Efecto cicatrizante del aceite de Copaifera officinalis (copaiba), en pacientes con úlcera péptica. An Fac Med. 2011;72(2):113-7.
7. Comelli Jr E, Skinovski J, Sigwalt MF, Branco AB, Luz SR, Baulé Cde P. Rupture point analysis of intestinal anastomotic healing in rats under the action of pure Copaíba (Copaifera langsdorfii) oil. Acta Cir Bras. 2010; 25(4):362-7.

8. Pieri FA, Mussi MC, Fiorini JE, Moreira MA, Schneedorf JM. Bacteriostatic effect of copaiba oil (Copaifera officinalis) against Streptococcus mutans. Braz Dent J. 2012;23(1):36-8.

9. Santos AO, Ueda-Nakamura T, Dias Filho BP, Veiga Jr VF, Pinto AC, Nakamura CV. Antimicrobial activity of Brazilian copaiba oils obtained from different species of the Copaifera genus. Mem Inst Oswaldo Cruz. 2008; 103(3):277-81.

10. Deus RJA, Alves CN, Arruda MSP. Avaliação do efeito antifúngico do óleo resina e do óleo essencial de copaíba (Copaifera multijuga Hayne). Rev Bras Plantas Med. 2011;13(1):1-7.

11. Mendonça DE, Onofre SB. Atividade antimicrobiana do óleo-resina produzido pela copaiba Copaifera multijuga Hayne (Leguminosae). Rev Bras Farmacog. 2009;19(2):577-81.

12. Pieri FA, José RM, Galvão NN, Nero LA, Moreira MAS. Antimicrobial activity of autoclaved and non-autoclaved copaiba oil on Listeria monocytogenes. Ciênc Rural. 2010;40(8):1797-801.

13. Paiva LA, Gurgel LA, Silva RM, Tomé AR, Gramosa NV, Silveira ER, et al. Anti-inflammatory effect of kaurenoic acid, a diterpene from Copaifera langsdorffi on acetic acid-in- 
duced colitis in rats. Vascul Pharmacol. 2002; 39(6):303-7.

14. Johnson JR, Delavari P, Azar M. Activities of a nitrofurazone-containing urinary catheter and a silver hydrogel catheter against multidrug-resistant bacteria characteristic of catheter-associated urinary tract infection. Antimicrob Agents Chemother.1999:43(12):2990-5.

15. Diogo-Filho A, Lazarini BCM, Vieira-Junyor F, Silva GJ, Gomes HL. Avaliação das aderências pós-operatórias em ratos submetidos a peritoniostomia com tela de polipropileno associada à nitrofurazona. Arq Gastroenterol. 2004;41(4):245-9.

16. Martins NLP, Malafaia O, Ribas-Filho JM, Heibel M, Baldez RN, Vasconcelos PRL, et al. Análise comparativa da cicatrização da pele com o uso intraperitoneal de extrato aquoso de Orbignya phalerata (babaçu). Estudo controlado em Ratos. Act Cir Bras. 2006;21(Suppl 3):66-75.

17. Francisco JS, Moraes HP, Dias EP. Evaluation of the Image-Pro Plus 4.5 software for automatic counting of labeled nuclei by PCNA immunohistochemistry. Braz Oral Res. 2004;18(2):100-4.
18. Estevão LRM, Medeiros JP, Scognamillo-Szabó MVR, Baratella-Evêncio L, Guimarães EC, Câmara $C A G$, et al. Neoangiogênese de retalhos cutâneos em ratos tratados com óleo de copaíba. Pesq Agropec Bras. 2009;44(4):406-12.

19. Gonçalves RO, Moraes e Silva E, Lopes-Filho GJ. Immunohistochemical evaluation of fibrillar components of the extracellular matrix of transversalis fascia and anterior abdominal rectus sheath in men with inguinal hernia. Rev Col Bras Cir. 2014;41(1):23-9.

Received in: 19/07/2016

Accepted for publication: 26/09/2016

Conflict of interest: none.

Source of funding: Institutional Program of Scientific Initiation Grants (PIBIC), granted by CNPq to the student Carlos Augusto Nunes Martini.

\section{Mailing address:}

Carlos Augusto Nunes Martini

E-mail: carlos-martini@hotmail.com 